\title{
Macagigantin, a farnesylated flavonol from Macaranga gigantea
}

\author{
Mulyadi Tanjung a , Euis H. Hakim ${ }^{\mathrm{a}}$, Didin Mujahidin ${ }^{\mathrm{a}}$, Muhammad Hanafi ${ }^{\mathrm{b}}$ \\ and Yana M. Syaha* \\ ${ }^{a}$ Natural Products Chemistry Research Group, Organic Chemistry Division, Institut Teknologi \\ Bandung, Jalan Ganesha 10, Bandung 40132, Indonesia; ${ }^{b}$ Indonesian Institute of Science, Research \\ Center for Chemistry, Serpong, 15310 Tangerang, Indonesia
}

(Received 29 April 2009; final version received 1 September 2009)

\begin{abstract}
A new farnesylated flavonol derivative, macagigantin (1), together with two known flavonoids, glyasperin A (2) and apigenin (3), had been isolated from the acetone extract of the leaves of Macaranga gigantea. The structure of the new compound was elucidated as 6-farnesylkaempferol based on its spectroscopic data, including UV, IR, 1D and 2D NMR, and HR-EI-MS spectra. Compounds 1-3 were evaluated for their cytotoxic properties against $\mathrm{P}-388$ cells, their $\mathrm{IC}_{50}$ values being $11.3,6.0$, and $5.1 \mu \mathrm{M}$, respectively.
\end{abstract}

Keywords: macagigantin; farnesylated flavonol; Macaranga gigantea; Euphorbiaceae; cytotoxicity; P-388 cells

\section{Introduction}

The genus Macaranga (Euphorbiaceae) contains about 250 species distributed very widely from Africa and Madagascar in the west to tropical Asia, North Australia, and Pacific Islands in the east [1]. This genus has been shown to produce a number of phenolic compounds, particularly flavonoids and stilbenoids [2]. Recently, we have reported the first dihydrochalcone derivatives, along with flavanones, from an endemic Macaranga species in Indonesia, Macaranga trichocarpa [3]. In continuation of our phytochemical work on Indonesian tropical plants aiming to find new cytotoxic compounds [4-9], we had examined another Macaranga species, Macaranga gigantea (Reichb.f. \& Zoll.) Müll. Arg. In this paper, we report the isolation of a farnesylated flavonol, 6farnesylkaempferol (1), together with two known compounds 2 and 3 (Figure 1), from the acetone extract of the title plant leaves. The cytotoxic properties of compounds 1-3 against murine leukemia P388 cells are also briefly described.

\section{Results and discussion}

Compound $\mathbf{1}$ was isolated as a yellow solid and the molecular formula $\mathrm{C}_{30} \mathrm{H}_{34} \mathrm{O}_{6}$ was deduced from its HR-EI-MS data. The UV spectrum of $\mathbf{1}$ exhibited maxima typical for a flavonol structure $\left(\lambda_{\max } 271,348\right.$, and $283 \mathrm{~nm}$ ), and showed bathochromic shifts on addition of $\mathrm{AlCl}_{3}$ and $\mathrm{NaOAc}$ [10]. The IR spectrum indicated absorptions for hydroxyl $\left(3419 \mathrm{~cm}^{-1}\right)$, conjugated carbonyl $\left(1649 \mathrm{~cm}^{-1}\right)$, and aromatic (1608 and $1560 \mathrm{~cm}^{-1}$ ) groups. In the ${ }^{13} \mathrm{C}$ NMR spectrum (APT experiment; Table 1), 28 carbon signals representing 30 carbon atoms were observed. Two of them,

*Corresponding author. Email: yana@chem.itb.ac.id 